\title{
ANALISIS TEKNIS DAN EKONOMIS PADA DESAIN ALAT REAKTOR LIKUIFIKASI PADA INDUSTRI GULA
}

\section{TECHNICAL AND ECONOMIC ANALYSIS ON THE DESIGN OF LIQUEFACTION REACTOR OF SUGAR INDUSTRY}

\author{
Aditya Irfansyah, Sukma Naufal Sudarsono, Erwan Adi Saputro* \\ Teknik Kimia, Fakultas Teknik, Universitas Pembangunan Nasional 'Veteran' Jawa Timur, Jl. \\ Rungkut Madya No.1, Gunung Anyar, Kota Surabaya, Jawa Timur 60294, Indonesia \\ *erwanadi.tk@upnjatim.ac.id
}

\begin{abstract}
Abstrak
Pada setiap industri kimia, reaktor memegang peranan penting sebagai tempat terjadinya reaksi kimia. Salah satunya adalah reaktor likuifikasi pada industri pembuatan gula. Reaktor likuifikasi merupakan suatu tangki yang didalamnya terjadi proses hidrolisis yang mengubah larutan pati atau karbohidrat untuk dijadikan molekul yang lebih sederhana, seperti golongan desktrin, glukosa dan maltosa menggunakan bantuan enzim $\alpha$-amilase. Penelitian ini bertujuan untuk memprediksi harga reaktor likuifikasi di masa yang akan datang berdasarkan spesifikasi alat. Penelitian ini dilakukan dengan menentukan spesifikasi alat berdasarkan kapasitas dan menghitung penentuan harga alat menggunakan metode persamaan least square, yang nantinya harga tersebut dibandingkan dengan harga di pasaran saat ini. Berdasarkan perhitungan penentuan harga reaktor likuifikasi hasilnya sesuai dengan harga yang ada dipasaran saat ini. Sehingga metode perhitungan ini memadai untuk memprediksi harga reaktor likuifikasi.
\end{abstract}

Kata kunci: alat, harga, likuifikasi, reaktor, spesifikasi

\begin{abstract}
In every chemical industry, reactors play an important role as a place for chemical reactions to occur. One of them is the liquefaction reactor in the sugar manufacturing industry. The liquefaction reactor is a tank in which a hydrolysis process occurs which converts the starch or carbohydrate solution into simple molecules, such as glucose, maltose and dextrin with the help of the $\alpha$-amylase enzyme. This study aims to predict the price of the liquefaction reactor in the future based on the specifications of the equipment. This research was conducted by determining the specification of the tool based on the capacity and calculating the price of the tool using method of least square equation, which it will be later to compare the price with the price on the market. Based on the calculation of the price determination of the liquefaction reactor, the results are in accordance with the current market price. So that this calculation method is sufficient to predict the price of the liquefaction reactor
\end{abstract}

Keywords: equipment, liquefaction, price, reactor, specification

\section{Pendahuluan}

Gula tebu adalah salah satu dari kebutuhan pokok masyarakat di Indonesia sebagai zat pemanis. Kebutuhan gula tebu di Indonesia semakin meningkat setiap tahunnya. Penggunaan yang paling besar adalah dari sektor makanan dan minuman. Adapun kekurangan bahan pemanis alam seperti gula tebu mendorong masyarakat untuk mengkonsumsi gula sintesis (buatan) seperti Sorbitol. Bahan pemanis selain gula tebu atau sukrosa perlu dikembangkan untuk mengatasi masalah tersebut. Pemanis lain tersebut adalah gula sintesis dala bentuk cair maupun kristal. Gula cair dapat dibuat dari hidrolisis bahan yang menggunakan pati, baik dengan metode katalitik asam maupun dengan enzimatis. Bahan yang mengandung pati seperti tepung tapioka, tepung jagung dan tepung beras. Menurut (Triyono, 2008), pembuatan gula cair dengan metode hidrolisis pati secara enzimatis dapat memperoleh hasil rendemen dan mutu gula cair yang lebih tinggi atau memiliki konversi lebih tinggi dibandingkan dengan metode hidrolisis mengunakan senyawa asam. Oleh karena itu, dalam proses hidrolisis enzimatis, salah satu proses penting yang dibutuhkan adalah proses likuifikasi (Sutamihardja et al., 2017). Di Indonesia sangat kaya akan bahan baku dari alam yang mengandung pati atau karbohidrat. Demi mencukupi kebutuhan gula pemanis di Indonesia ini maka untuk pembuatan gula sintesis seperti sorbitol sangat efektif. Berikut ini adalah daftar bahan baku dengan kandungan pati yang melimpah di Indonesia dan dapat digunakan sebagai bahan baku pembuatan gula sintesis seperti sorbitol dan matitol. 
Tabel 1. Kandungan Pati dalam Bahan Baku

\begin{tabular}{|l|c|c|c|c|c|}
\hline \multicolumn{1}{|c|}{ Komposisi Kimia } & $\begin{array}{c}\text { Tepung } \\
\text { Singkong/Tapioka }\end{array}$ & $\begin{array}{c}\text { Tepung } \\
\text { Terigu }\end{array}$ & $\begin{array}{c}\text { Tepung } \\
\text { Jagung }\end{array}$ & $\begin{array}{c}\text { Tepung } \\
\text { Kentang }\end{array}$ & $\begin{array}{c}\text { Tepung } \\
\text { Beras }\end{array}$ \\
\hline Karbohidrat/Pati (g) & 88,2 & 77,3 & 73,7 & 85,6 & 80 \\
\hline Protein (g) & 1,1 & 8,9 & 9,2 & 0,3 & 7,0 \\
\hline Lemak (g) & 0,5 & 1,3 & 3,9 & 0,1 & 0,5 \\
\hline Kalori (cal) & 363 & 365 & 355 & 347 & 353 \\
\hline
\end{tabular}

2018)

(Direktorat Pangan Departemen Kesehatan Republik Indonesia,

Likuifikasi adalah suatu proses dalam hidrolisis pati menjadi molekul-molekul yang lebih sederhana seperti maltosa, glukosa dan dekstrin dengan menggunakan batuan enzim $\alpha$-amilase. Likuifikasi bahan pati umumnya diproses hingga tercapai dekstrosa equivalen sebesar 15-20\% atau sampai larutan slurry berwarna merah bata apabila direaksikan dengan larutan iodin. Aktivitas dari kemampuan enzim $\alpha$-amilase menentukan cepat lambatnya dalam proses likuifikasi. Proses ini dilakukan pada kondisi temperatur $105^{\circ} \mathrm{C}$ dengan $\mathrm{pH}=6$ selama 5 menit atau pada temperatur $95-97{ }^{\circ} \mathrm{C}$ dengan $\mathrm{pH}=6$ selama $1-3$ jam, dengan penambahan enzim $\alpha-$ amilase secara stabil (Rahmawati \& Sutrisno, 2015). Penambahan dosis enzim $\alpha$-amilase adalah $0,5-0,6 \mathrm{~kg}$ per ton pati kering (Santoso, 2010)

Peranan reaktor likuifikasi memegang kunci penting dalam proses pembuatan gula cair. Spesifikasi reaktor likuifikasi secara umum membutuhkan pengaduk, karena saat prosesnya, dua zat yang berbeda fase dicampurkan di dalam reaktor. Fungsi dari pengaduk ialah untuk memudahkan homogenisasi bahan - bahan di dalam reaktor agar dapat bereaksi secara sempurna. Selain itu, dibutuhkan media penjaga suhu operasi, hal ini dibutuhkan agar kondisi operasi tetap terjaga untuk reaksi berjalan secara optimal (Dewi et al., 2014). Reaksi likuifikasi bersifat endotermis karena memiliki nilai $\Delta \mathrm{H}_{\text {reaksi }}$ bernilai positif yang menunjukkan bahwa reaksi menyerap panas sehingga membutuhan steam untuk menstabilkan kondisi suhu operasi dari reaktor likuifikasi. Reaksi pembentukan dekstrin berlansung dalam fase cair dan bersifat irreversible. Dekstrin terbentuk melalui 2 tahap yaitu gelatinase kemudian likuifikasi. Hidrolisis terjadi di tahap likuifikasi (Ullmann, 2002)

Penelitian ini memiliki tujuan untuk memperkirakan harga alat reaktor likuifikasi di masa yang akan datang didasarkan pada perhitungan spesifikasi alat. Berikut merupakan sketsa dari reaktor likuifikasi berbentuk silinder (vertical) dengan pengaduk dan disertai coil pemanas:

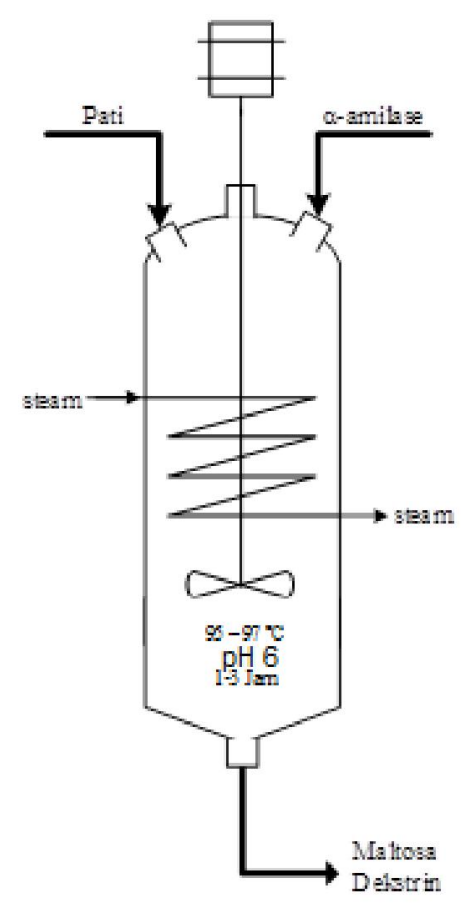

Gambar 1. Sketsa Reaktor Likuifikasi 


\section{Metodologi Penelitian}

Penelitian ini dilakukan dengan menggunakan perhitungan spesifikasi alat reaktor likuifikasi dan menentukan harga alat reaktor likuifikasi yang dibandingkan dengan harga reaktor likuifikasi yang ada di pasaran

\section{Rumus menghitung spesifikasi Alat Reaktor Likuifikasi:}

Langkah - langkah menghitung spesifikasi alat reaktor likuifikasi adalah:

(1) Menentukan laju alir massa dan panas bahan masuk dan keluar ke reaktor likuifikasi

(2) Menentukan volume tangki, dengan ketentuan volume larutan mengisi $80 \%$ volume tangki total. Perhitungan meliputi:

a. Mengasumsi $\mathrm{H}=2 \mathrm{D}$, lalu menentukan diameter dengan menghitung

Volume total $=$ volume silinder + volume tutup bawah + volume tutup atas

b. Volume silinder $\mathrm{Vs}=(\pi / 4) \times \mathrm{D}^{2} \times \mathrm{Hs}$

c. Volume tutup bawah

Vtutup bawah $=0,262 \times \mathrm{H}$ tutup bawah $\left(\mathrm{D}^{2}+\mathrm{Dm}+\mathrm{m}^{2}\right)$

d. Volume tutup atas

Vtutup atas $=0,000049 \times \mathrm{D}^{3}$

keterangan:

$$
\begin{array}{ll}
\mathrm{Hs} & =\text { tinggi dari silinder }(\mathrm{ft}) \\
\mathrm{D} & =\text { diameter dari silinder }(\mathrm{ft}) \\
\mathrm{Vs} & =\text { volume dari silinder }(\mathrm{cuft}) \\
\mathrm{m} & =\text { flat spot center }(0.105 \mathrm{D})
\end{array}
$$

(3) Bahan konstruksi berupa Carbon Steel - SA 105

(4) Menentukan ketinggian yang meliputi:

a. Tinggi bahan $\mathrm{Hf}=\left((\pi / 4) \times \mathrm{D}^{2}\right) /$ Volume bahan

b. Tinggi silinder

$\mathrm{H}=2 \mathrm{D}$.

c. Tinggi tutup bawah

Htutup bawah $=\frac{\tan \alpha x(D-m)}{2}$

d. Tinggi tutup atas

$\mathrm{BC}=\mathrm{rc}-\mathrm{icr}$

$\mathrm{AB}=0,5 \times(\mathrm{Di}-\mathrm{icr})$

$\mathrm{b}=\mathrm{rc}-\sqrt{B C^{2}-A B^{2}}$

Htutup atas $=\mathrm{b}+\mathrm{sf}+\mathrm{t}$ dimana:

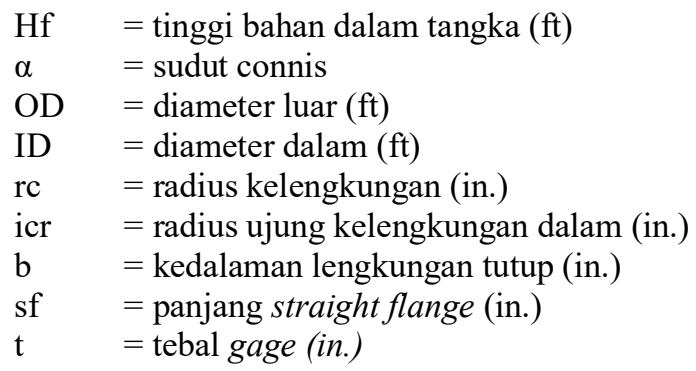

(5) Menentukan tekanan desain tangki yang meliputi:

a. Tekanan hidrostatis

P hidrostatis $=\frac{\rho \times\left(\frac{g}{g c}\right) \times h}{144}$

b. P operasi $=14.7$ psia

c. $\mathrm{P}$ desain (diasumsikan $10 \%$ dari jumlah $\mathrm{P}$ operasi $+\mathrm{P}$ hidrostatis agar lebih aman)

$\mathrm{P}$ terukur dalam tangki $=\mathrm{P}$ hidrostatis $-\mathrm{P}$ operasi

dimana:

$\rho \quad=\operatorname{densitas}\left(\mathrm{lb} / \mathrm{ft}^{3}\right)$
$\mathrm{H}=\mathrm{D}=\operatorname{diameter}(\mathrm{ft})$ 
$\mathrm{g} / \mathrm{gc}=1 \mathrm{lbf} / \mathrm{lbm}$

(6) Menentukan tebal tangki yang meliputi:

a. Mencari data - data pada buku Brownell \& Young, Process Equipment Design antara lain: Faktor korosi, faktor pengelasan, nilai stress allowable dari jenis bahan konstruksi

b. Menghitung tebal shell minimum $\mathrm{t} \min =\frac{P \times r i}{f \times E-0.6 \times P}+C$

c. Menghitung tebal tutup bawah dengan menentukan bentuk tutup terlebih dahulu t tutup bawah $=\frac{P \times D}{2 \cos \alpha(f \times E-0.6 \times P)}+C$

d. Menghitung kebutuhan cincin penguat jika $\Delta<30^{\circ}$

$\Delta$ didapatkan berdasarkan tabel 13.3 Brownell dengan menghitung $\mathrm{p} / \mathrm{fE}$

e. Menghitung tebal tutup atas dengan menentukan bentuk tutup terlebih dahulu

$\mathrm{W}=0.25 \times(3+\sqrt{r c / i c r})$

t tutup atas $=\frac{P \times r c \times W}{2 f \times E-0.2 \times P)}+C$

dimana:

$$
\begin{array}{ll}
\mathrm{t} \text { tutup } & =\text { tebal (in.) } \\
\mathrm{P} & =\text { tekanan desain alat (psia) } \\
\mathrm{ri} & =\text { jari }- \text { jari dalam alat (in.) } \\
\mathrm{f} & =\text { stress allowable }(\mathrm{psi}) \\
\mathrm{E} & =\text { faktor pengelasan } \\
\mathrm{C} & =\text { faktor korosi (in.) } \\
\mathrm{W} & =\text { berat aliran }(\mathrm{lb} / \mathrm{jam})
\end{array}
$$

(7) Menentukan nozzle outlet larutan, dengan asumsi aliran turbulen

Diameter nozzle optimum $=3,9 \times \mathrm{qf}^{0,45} \times \rho^{0,13}$ dimana:

$$
\begin{array}{ll}
\mathrm{qf} & =\text { fluid flowrate }\left(\mathrm{ft}^{3} / \text { detik }\right) \\
\rho & =\operatorname{densitas}\left(\mathrm{lb} / \mathrm{ft}^{3}\right)
\end{array}
$$

(8) Pengaduk yang digunakan, meliputi:

a. Jenis pengaduk adalah flat blade turbine

b. Menentukan jenis pengaduk berdasarkan sifat liquida di dalam tangki

c. Menentukan dimensi pengaduk

Diameter impeller $(\mathrm{Da})=1 / 3$ Diameter tangka $(\mathrm{Dt})$

Lebar blade pengaduk $(\mathrm{W})=1 / 5 \mathrm{Da}$

Panjang blade pengaduk $(\mathrm{L})=(1 / 4) \mathrm{Da}$

Jarak impeller dari dasar $(\mathrm{E})=1 / 3 \mathrm{Dt}$

d. Menentukan jumlah pengaduk

$\mathrm{Sg}=\left(\rho\right.$ bahan $/ \rho$ reference $\left.\left(\mathrm{H}_{2} \mathrm{O}\right)\right)$

Jumlah impeller $=\frac{\text { tinggi larutan }}{\text { diameter bejana }} \times s g$

e. Menentukan jumlah putaran pengaduk $(\mathrm{N})$

$\mathrm{V}=\pi \times \mathrm{N} \times \mathrm{Da}$

$\mathrm{V}$ harus memenuhi range antara $200-250 \mathrm{~m} / \mathrm{menit}$ dengan trial nilai $\mathrm{N}$

f. Menentukan kebutuhan baffle

$\mathrm{NRe}=\frac{\rho x D a^{2} x N}{\mu}$

Jika NRe $>10000$, maka digunakan baffle sejumlah 4 dengan sudut $90^{\circ}$

Lebar baffle $(\mathrm{J})=(1 / 12) \times$ Diameter tangki

g. Menentukan power (tenaga) dari pengaduk

$\mathrm{P}=\left(\mathrm{K}_{3} / \mathrm{g}\right) \times \rho_{\text {bahan }} \times \mathrm{N}^{3} \times \mathrm{Da}^{5}$

Untuk losses pengaduk:

- Gland losses (kebocoran tenaga oleh poros dan bearing) $=10 \% \times \mathrm{P}$

- $\quad$ Transmission system losses $=20 \% \times \mathrm{P}$

- $\quad$ Power input $=\mathrm{P}+$ gland losses + transmission system losses

Power input motor sebenarnya $=$ Power input $/$ Efisiensi

dimana:

$$
\begin{array}{ll}
\mathrm{sg} & =\text { specific gravity } \\
\mathrm{V} & =\text { peripheral speed }(\mathrm{m} / \text { menit }) \\
\mathrm{Da} & =\text { diameter impeller }(\mathrm{ft})
\end{array}
$$


$\mu \quad=$ viskositas liquida (lb/ft.detik)

(9) Menentukan coil pemanas

a. Menentukan suhu feed (T1), suhu produk (T2), suhu steam masuk (t1) dan keluar (t2)

b. Menentukan Q supply dan kebutuhan steam dari neraca energi

c. Menentukan LMTD

$\Delta \mathrm{LMTD}=\frac{\left(\Delta t_{1}-\Delta t_{2}\right)}{\ln \left(\frac{\Delta t_{1}}{\Delta t_{2}}\right)}$

d. Menentukan temperature caloric

e. Menghitung spesifikasi coil

ho $=\mathrm{j} \times(\mathrm{k} / \mathrm{ID}) \times[\mathrm{c} . \mu / \mathrm{k}]^{1 / 3} \times[\mu / \mu \mathrm{w}]^{0.14}$

dimana dengan menetapkan putaran pengaduk $(\mathrm{N})$ dan diameter pipa coil, data - data seperti densitas (air dan larutan), viskositas (air dan larutan), nilai j dan k pada buku D.Q Kern, Process Heat Transfer.

$\mathrm{Uc}=($ hio.ho $) /($ hio + ho $)$ dengan hio $($ steam $)=1500 \mathrm{BTU} / \mathrm{jam} . \mathrm{ft}^{2} .{ }^{\circ} \mathrm{F}$

$\mathrm{Rd}=(\mathrm{Uc}-\mathrm{Ud}) /(\mathrm{Uc} . \mathrm{Ud})$

$\mathrm{A}=\mathrm{Q} /(\mathrm{Ud} \times \Delta \mathrm{t})$

$\mathrm{L}=\mathrm{A} / \mathrm{a} "$

$\mathrm{nc}=\mathrm{L} /(\pi \times \mathrm{Dc})$

$\mathrm{Lc}=(\mathrm{nc}-1) \times((\mathrm{hc}+\mathrm{do})+\mathrm{do})$

dimana:

ho $\quad=$ koefisien heat transfer untuk liquid bagian luar $\left(\mathrm{Btu} / \mathrm{jam} . \mathrm{ft}^{2} .{ }^{\circ} \mathrm{F}\right)$

hio $\quad=$ bagian coil (steam); $1500 \mathrm{Btu} / \mathrm{jam} . \mathrm{ft}^{2}{ }^{\circ} \mathrm{F}$

Uc $\quad=$ heat transfer coefficient pipa dalam keadaan bersih $\left(\mathrm{Btu} / \mathrm{jam} . \mathrm{ft}^{2} .{ }^{\circ} \mathrm{F}\right)$

$\mathrm{Ud} \quad=$ heat transfer coefficient pipa dibutuhkan dalam desain $\left(\mathrm{Btu} / \mathrm{jam} . \mathrm{ft}^{2}{ }^{\circ} \mathrm{F}\right)$

Rd = dirt factor

nc $\quad=$ jumlah lilitan coil

Dc $\quad=$ diameter coil $(\mathrm{ft})$

Lc $\quad=$ tinggi coil $(\mathrm{ft})$

\section{Rumus Penentuan Harga Alat}

(1) Menentukan indeks harga alat yang diperoleh dari CEPCI (Chemical Engineering Plant Cost Index) tahun 2020.

(2) Menentukan harga alat dari situs (www.matche.com) dengan memasukkan nilai kondisi dan spesifikasi dari perhitungan reaktor likuifikasi, diantaranya adalah jenis reaktor, materia, tekanan operasi, dan volume reaktor.

(3) Menghitung indeks harga dengan metode least square:

Nilai X : Tahun

Nilai Y : Indeks harga

$\mathrm{X} . \mathrm{Y}: \mathrm{X}^{2} \mathrm{x} \mathrm{Y}^{2}$

(4) Menghitung rumus dari persamaan 21 pada literatur Peters \& Timmerhauss, yaitu:

$$
\begin{aligned}
& \sum(\bar{x}-x)^{2}=\sum x^{2}-\frac{\left(\sum x\right)^{2}}{n} \\
& \sum(\bar{y}-y)^{2}=\sum y^{2}-\frac{\left(\sum y\right)^{2}}{n}
\end{aligned}
$$

(5) Menghitung rumus dari persamaan 21 menurut Max et al., (2003), yaitu:

$$
\sum(\bar{x}-x)(\bar{y}-y)=\sum x y-\frac{\sum x \sum y}{n}
$$




$$
b=\frac{\sum(\bar{x}-x)(\bar{y}-y)}{\sum(\bar{x}-x)^{2}}
$$

(6) Menentukan rata-rata dari nilai $X$ dan rata-rata nilai $Y$

(7) Membuat persamaan dari perhitungan poin (3) sampai (4), yaitu:

$$
y=a+b(x-c) \text {. }
$$
dimana:

$$
\begin{aligned}
\mathrm{a} & =\text { nilai rata }- \text { rata } \mathrm{Y} \\
\mathrm{c} & =\text { nilai rata }- \text { rata } \mathrm{X} \\
\mathrm{X} & =\text { harga alat pada tahun } \mathrm{ke}-\mathrm{x}
\end{aligned}
$$

Hasil

\section{Perhitungan Spesifikasi Harga dan Alat}

Ditentukan:

Kapasitas $1 \quad: 60.000$ ton/tahun

Kapasitas $2 \quad: 70.000$ ton/tahun

Kapasitas $3: 90.000$ ton/tahun

Kapasitas $4 \quad: 100.000$ ton/tahun

Kapasitas $5 \quad: 110.000$ ton/tahun

Tabel 2. Perhitungan Spesifikasi Alat

\begin{tabular}{|l|c|c|c|c|c|}
\hline \multicolumn{1}{|c|}{ Spesifikasi alat } & Kapasitas 1 & Kapasitas 2 & Kapasitas 3 & Kapasitas 4 & Kapasitas 5 \\
\hline Diameter tangki(ft) & $8,095(2,467)$ & $8,522(2,597)$ & $9,267(2,824)$ & $9,598(2,925)$ & $9,908(3,020)$ \\
\hline Harga (US\$) pada tahun 2014 & 101.500 & 110.200 & 127.500 & 133.100 & 140.000 \\
\hline
\end{tabular}

Berdasarkan tabel 1, kapasitas pertama yaitu 60.000 ton/tahun membutuhkan diameter tangki reaktor likuifikasi sebesar 8,095 ft untuk menjalankan proses likuifikasi secara optimal dengan perkiraan harga pada tahun 2014 sebesar US\$ 101.500. Selanjutnya, saat kapasitas dinaikkan, yaitu 70.000 ton/tahun dibutuhkan diameter tangki sebesar 8,522 ft dengan perkiraan harga pada tahun 2014 sebesar US\$ 110.200. Sedangkan saat kapasitas dinaikkan lagi, yaitu 90.000 ton/tahun dibutuhkan diameter tangki yang lebih besar yaitu 9,2657 ft dengan perkiraan harga pada tahun 2014 sebesar US\$127.500.

\section{Hubungan Kapasitas Dengan Harga Alat}

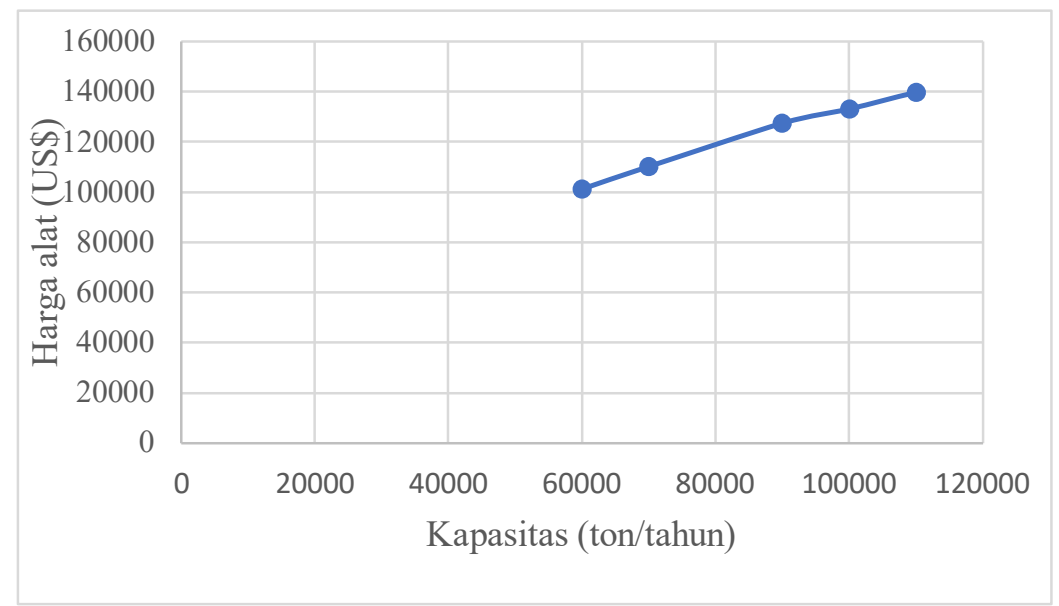

Gambar 2. Grafik hubungan antara kapasitas (ton/tahun) dan harga alat (US\$) 
Pada grafik pada gambar 2, dapat dikatakan bahwa harga alat reaktor likuifikasi dipengaruhi oleh seberapa besarnya diameter tangki. Semakin besar kapasitas produksi, maka umpan yang masuk ke dalam reaktor juga akan semakin banyak, sehingga dibutuhkan dimensi tangki yang lebih besar agar mencukupi jumlah umpan yang masuk, salah satunya adalah diameter tangki. Selain itu, dengan bertambahnya ukuran diameter tangki reaktor likuifikasi, maka biaya pembuatan alat reaktor likuifikasi akan semakin mahal. Penentuan harga dari reaktor juga di pengaruhi oleh komponen pendukung dalam reaktor seperti koil pemanas dan jenis pengaduk. Koil pemanas dipilih karena lebih efektif dalam melakukan proses pemanasan di dalam vessel. Jenis koil mempunyai harga yang kebih terjangkau dari pada menggunakan mantel dalam proses pemasanganya dalam reaktor likuifikasi. Jenis komponen pendukung akan mempengaruhi biaya yang dibutuhkan dalam merancang reaktor likuifikasi ini.

Berdasarkan dari situs (www.alibaba.com) Weihai Zhengwei Machinery Co., Ltd sebagai acuan harga pasaran reaktor silinder dengan pengaduk seperti pada desain di berbagai volume kapasitas diperoleh sebagai berikut :

Tabel 3. Harga Reaktor Menurut Pasar

\begin{tabular}{|c|c|c|}
\hline No & Volume Kapasitas (Liter) & Harga (US\$) \\
\hline 1. & 100 & 20.000 \\
\hline 2. & 300 & 21.000 \\
\hline 3. & 1000 & 25.000 \\
\hline 4. & 3000 & 35.000 \\
\hline
\end{tabular}

\section{Analisis Perbandingan dengan Harga Pasar}

Berdasarkan tinjauan pada laman Alibaba.com, alat reaktor dengan kapasitas 50L-20.000L dijual dengan harga US\$ 9.980 hingga US\$ 150.000 (Fujian Qiquan, 2021). Jika 20.000L digunakan sebagai contoh, maka didapat harga US\$ 150.000. Padahal dengan harga sebanyak itu dapat digunakan untuk membuat alat reaktor likuifikasi dengan kapasitas 120.000 ton/tahun.

\section{Kesimpulan}

Berdasarkan estimasi perhitungan harga alat reaktor likuifikasi, dapat disimpulkan bahwa semakin besar kapasitas produksi, maka harga perancangan alatnya akan semakin tinggi harganya. Hal ini dibuktikan dengan hasil dari perhitungan dengan kapasitas produksi 60.000 ton/tahun, harga alat mencapai US\$ 101.500, saat kapasitas produksi dinaikkan 20.000 ton/tahun, harga alat naik sebesar US\$ 26.000, yakni mencapai US\$ 127.500. Sehingga kesimpulan yang didapatkan yaitu metode perhitungan ini memadai dan dapat digunakan dalam estimasi harga alat untuk perancangan pabrik.

\section{Daftar Pustaka}

Brownell, Lloyd E. and Young, Edwin H, Process Equipment Design, Wiley Eastern Limited, New Delhi, 1959 Dewi, H. K., Puspasari, D. A., \& Widjaja, A. (2014). Pra Desain Pabrik Sorbitol dari Tepung Tapioka dengan Hidrogenasi Katalitik. 3(1), 1-6.

Direktorat Pangan Departemen Kesehatan Republik Indonesia. (2018). Komposisi Gizi Pangan. Panganku.Org. Panganku.org/id-ID/,2018

Fujian Qiquan. (2021). Mamalia Kultur Sel Bioreaktor Tetap Fluidized Bed Cell Culture. Alibaba.Com. https://indonesian.alibaba.com/product-detail/mammalian-cell-culture-bioreactor-fixed-fluidized-bed-cellculture-1600103686572.html?spm=a2700.galleryofferlist.normal_offer.d_title.178214d4GacnrK

Geankoplis, C.J and J.F Richardson, Design Transport Process and Unit Operation, Peramon Press, Singapore, 1989.

Kern, Donald Q, Process Heat Transfer, McGRAW-Hill International Book Company, Tokyo, 1965.

Ludwig. E, Applied Process Design For Chemical And Petrochemical, Vol I, Gulf publishing Co, Houston, Texas, 1964.

Max, S. P., Klaus, D. T., \& Ronald, E. W. (2003). Plant Design and Economics for Chemical Engineers. McGraw-Hill Companies.

McCabe, W., Smith, J.C, and Harriot, P., Unit Operation of Chemichal Engineering, McGraw Hill Book, co., United States of America, 1993. 
Perry, R.H., and Green, D.W., Perry's Chemical Engineers Hand Book $6^{\text {th }}$ ed, McGraw Hill Book Company, Singapore, 1984.

Rahmawati, A. Y., \& Sutrisno, A. (2015). HIDROLISIS TEPUNG UBI JALAR UNGU (Ipomea batatas L.) SECARA ENZIMATIS MENJADI SIRUP GLUKOSA FUNGSIONAL: KAJIAN PUSTAKA. Pangan Dan Agroindustri, 3(3), 1152-1159.

Santoso, H. (2010). Hidrolisa Enzimatik Pati Tapioka dengan Kombinasi Pemanas Microwave-Water Bath pada Pebuatan Dekstrin. Jurnal Teknik Kimia Momentum, 6(2), 29-35.

Sutamihardja, R., Azizah, M., \& Mafiana, B. D. (2017). Perbandingan Hidrolisis Enzimatis dan Asam Terhadap Pati Jagung Manis (Zea Mays L.) dalam Pembuatan Gula Cair. Sains Natural Universitas Nusa Bangsa, $7(2), 58-67$.

Triyono, A. (2008). Karakterisasi Gula Glukosa dari Hasil Hidrolisa Pati Ubi Jalar (Ipomea Batatas, L.) dalam Upaya Pemanfaatan Pati Umbi -Umbian. Prosiding Seminar Nasional Teknoin 2008 Bidang Teknik Kimia Dan Tekstil, 5, 7-10.

Ullmann. (2002). Ullmann's Encyclopedia of Industrial Chemistry (6th ed.). Wiley-VCH Verlag GmbH \& Co. KGaA. https://doi.org/10.1002/14356007

Ulrich, G.G., A Guide to Chemical Engineering Process Design and Economic, John Willey and Sons, new York, 1984, p.249. 